\title{
Isolation of Bdellovibrio and like organisms and potential to reduce acute hepatopancreatic necrosis disease caused by Vibrio parahaemolyticus
}

\author{
Jetnapang Kongrueng ${ }^{1}$, Pimonsri Mitraparp-arthorn ${ }^{1}$, \\ Khotchawan Bangpanwimon ${ }^{1}$, William Robins ${ }^{2}$, V. Vuddhakul ${ }^{1, *}$, John Mekalanos ${ }^{2}$ \\ ${ }^{1}$ Food Safety and Health Research Unit, Department of Microbiology, Faculty of Science, Prince of Songkla University, \\ Hat Yai, Thailand \\ ${ }^{2}$ Dept. of Microbiology and Immunobiology, Harvard Medical School, Boston, MA 02115, USA
}

\begin{abstract}
Acute hepatopancreatic necrosis disease, a severe disease of shrimp, is caused by Vibrio parahaemolyticus (AHPND Vp), a halophilic bacterium harboring a plasmid that contains toxin genes homologous to Photorhabdus insect-related toxins. We obtained 9 isolates of Bdellovibrio and like organisms (BALOs) from water and sediment samples in Thailand. Using 16S rRNA sequencing, all of the organisms were identified as Bacteriovorax spp. and were able to attack all tested AHPND Vp isolates. In addition, their various susceptible hosts, including Gram-positive and Gram-negative bacteria, were observed. The optimal ratio for interaction between the Bacteriovorax isolate BV-A and AHPND Vp was determined to be 1:10. The suitable conditions applied for co-culture between BV-A and AHPND Vp were $30^{\circ} \mathrm{C}, 2 \% \mathrm{NaCl}$, and $\mathrm{pH}$ 7.6. The capability of BV-A to reduce numbers of AHPND Vp in vitro was observed in co-culture after incubation for $2 \mathrm{~d}$ and continued until the end of the incubation period. In vivo, BV-A was able to reduce mortality of shrimp post-larvae infected with AHPND Vp. In addition, BV-A significantly decreased the formation of biofilm by AHPND Vp. These findings provide evidence for using Bacteriovorax as a biocontrol of AHPND Vp in shrimp aquaculture.
\end{abstract}

KEY WORDS: Bdellovibrio and like organisms - BALOs · Bacteriovorax - Vibrio parahaemolyticus . Acute hepatopancreatic necrosis disease $\cdot$ AHPND $\cdot$ Shrimp

\section{INTRODUCTION}

Shrimp aquaculture is an enterprise that has generated substantial export income for many countries. Previously, Thailand was the world's leading producer of cultured shrimp, followed by China, India, Ecuador, Vietnam, and Indonesia. However, in 2009, a new shrimp disease, named acute hepatopancreatic necrosis disease (AHPND), emerged in China and subsequently spread to Vietnam, Malaysia, Thailand, and Mexico (Tran et al. 2013, Joshi et al. 2014, Nunan et al. 2014). The causative agent of AHPND is Vibrio parahaemolyticus, a halophilic Gram-negative bacterium found in marine and estuarine environments (Tran et

\footnotetext{
${ }^{*}$ Corresponding author: varaporn.v@psu.ac.th
}

al. 2013). AHPND V. parahaemolyticus (AHPND Vp) harbors a unique large plasmid containing genes encoded for toxin homologs to the Photorhabdus insectrelated toxins PirA and PirB (Yang et al. 2014). The bacterium affects post-larvae approximately 30 to $35 \mathrm{~d}$ after stocking the shrimp pond, causing massive rounding and sloughing of hepatopancreatic tubule epithelial cells in the early to mid stages of the disease (Hong et al. 2016). PirA is only present at the later stage, whereas PirB is detected in the hepatopancreas at the early stage of infection but is sufficient to cause cellular damage (Lai et al. 2015). This bacterium has been disastrous for the shrimp industry and has reduced shrimp production worldwide by up to $20 \%$

() The authors 2017. Open Access under Creative Commons by Attribution Licence. Use, distribution and reproduction are unrestricted. Authors and original publication must be credited. 
(Hong et al. 2016). Strenuous efforts to solve this problem have included cessation of shrimp cultivation and drying out of shrimp ponds for a period of time. However, the disease reoccurs after cultivation recommences. Therefore, pond management including biocontrol should be incorporated.

Bdellovibrio and like organisms (BALOs) are a group of small Gram-negative predatory bacteria that are ubiquitous in aquatic and terrestrial environments (Williams \& Pineiro 2006). BALOs can invade the periplasm and multiply inside many prey bacteria, lysing them and further attacking other bacteria. This makes BALOs potentially powerful inhibitors of environmentally and clinically undesirable bacteria (Fratamico \& Cooke 1996, Sockett \& Lambert 2004). BALOs have been investigated as alternative organisms for the prevention and control of bacterial disease in aquaculture. Bdellovibrio F16, isolated from sturgeon gut, displayed bacteriolytic activity against the fish pathogen Aeromonas hydrophila (Cao et al. 2012). Fish challenged by immersion in water containing A. hydrophila and Bdellovibrio C-1 suffered lower mortality than fish in water containing A. hydrophila alone, suggesting the possibility of using Bdellovibrio to control this bacterium in fish (Chu \& Zhu 2010). Two marine BALOs isolated from the sediment of a bay in China reduced total vibrios and $V$. parahaemolyticus in water and oyster intestine (Li et al. 2011). BALO strain BDHSH06 reduced the numbers of total bacteria and vibrios in pond water and shrimp intestine ( $\mathrm{Li}$ et al. 2014). To solve the problem of drug resistance, which causes complications in bacterial infection, 2 genera of BALOs (Bdellovibrio and Micavibrio) have been demonstrated to be capable of attacking many human pathogenic bacteria such as Enterobacter, Escherichia, Klebsiella, Proteus, Pseudomonas, Shigella, and Yersinia (Dashiff et al. 2011). Although BALOs attack bacteria nonspecifically, they preferentially select prey to different degrees (Williams \& Pineiro 2006). Therefore, it is of interest to investigate the potential of BALOs to eliminate AHPND Vp. The aims of this work were to isolate BALOs from various samples collected from AHPND shrimp ponds and to evaluate their potential to control the numbers of AHPND Vp in vitro and in vivo.

\section{MATERIALS AND METHODS}

\section{Bacterial strains and growth conditions}

AHPND Vp designated as PSU 5429, PSU 5499, PSU 5562, and PSU 5579 were isolated from AHPND- afflicted shrimp collected from various farms in southern Thailand (Kongrueng et al. 2015) and were used as mixed prey bacteria to isolate BALOs. AHPND Vp PSU 5429 was used as a host prey for other assays throughout this study. Each bacterium was grown in Luria-Bertani (LB) broth supplemented with $1 \% \mathrm{NaCl}$ at $30^{\circ} \mathrm{C}$ with shaking at $150 \mathrm{rpm}$ for $3 \mathrm{~h}$ and adjusted to $10^{8} \mathrm{CFU} \mathrm{m}{ }^{-1}$ using a densitometer (Densimat, bioMérieux). The bacterial cells were then spun down, and LB broth was replaced with diluted nutrient broth (DNB). Each $1 \mathrm{ml}$ of bacterial strain was mixed and used as a prey cocktail to isolate BALOs.

\section{Isolation and purification of BALOs}

Water and sediment field samples were collected off an island and from AHPND Vp-infected shrimp farms located in central and southern Thailand. Isolation of BALOs was performed using the double-layered plaque assay (Medina et al. 2008). Briefly, in the preenrichment step, a test sample of either $10 \mathrm{~g}$ or $10 \mathrm{ml}$ of sediment or water was mixed with $100 \mathrm{ml}$ of DNB (Starr 1975) and $1 \mathrm{ml}$ of prey cocktail $\left(10^{8} \mathrm{CFU} \mathrm{ml}{ }^{-1}\right)$. The mixture was incubated with shaking $(200 \mathrm{rpm})$ at $30^{\circ} \mathrm{C}$ for $7 d_{\text {; }}$ it was then centrifuged and the supernatant was passed through a $0.45 \mu \mathrm{m}$ membrane filter (Millipore). The filtrate was concentrated by centrifugation at $22000 \times g$ for $1 \mathrm{~h}$, and the pellet was re-suspended in DNB and mixed with $300 \mu$ l of prey cocktail $\left(10^{8} \mathrm{CFU}\right.$ $\left.\mathrm{ml}^{-1}\right)$; it was then overlaid on diluted nutrient agar (DNAg). The plate was incubated at $30^{\circ} \mathrm{C}$, and the development of plaque formation within 3 to $7 \mathrm{~d}$ indicated the presence of BALOs. Individual plaques were purified by 3 passages, and the BALOs were cultivated in DNB with AHPND Vp (PSU 5429) to enhance the titer and kept at $-80^{\circ} \mathrm{C}$ with $10 \%$ glycerol.

For any assay, each BALO was recovered from the stock and its titer was enhanced as described above. To enumerate the BALOs, a 10-fold dilution of BALO suspension was performed, and $100 \mu$ l of each dilution were mixed with $4 \mathrm{ml}$ of soft DNAg (0.6\% agar) containing $300 \mu \mathrm{l}$ of AHPND Vp PSU 5429 at a concentration of $10^{8} \mathrm{CFU} \mathrm{ml}{ }^{-1}$. The mixture was then overlaid on a DNAg plate and incubated at $30^{\circ} \mathrm{C}$. The numbers of plaques were counted after at least $3 \mathrm{~d}$ of incubation.

\section{Molecular identification}

To identify the genus of the BALOs, genomic DNA of BALOs was extracted by boiling. The 16S rRNA 
gene was amplified by PCR using primers specific to the Bdellovibrio $16 \mathrm{~S}$ rRNA gene $(63 \mathrm{~F}$ primer: 5 '-GAG GCC TAA CAC ATG CAA GTC-3'; 842R primer: 5'-CGW CAC TGA AGG GGT CAA-3') (Jurkevitch et al. 2000) and the Bacteriovorax 16S rRNA gene (Bac676F primer: 5'-ATT TCG CAT GTA GGG GTA3'; Bac1442R primer: 5'-GCC ACG GTT CAG GTA AG-3') (Davidov et al. 2006). The PCR product was electrophoresed on $1 \%$ agarose gel and was detected using a UV transilluminator. For sequencing, the PCR product was purified using a Qiagen kit and sequenced.

\section{Phylogenetic tree analysis}

The 16S rRNA sequences of BALOs obtained in this study were analyzed against the database at the National Center for Biotechnology Information (NCBI) using the Basic Local Alignment Search Tool (BLAST) program. The sequences of BALO isolates were aligned by ClustalW with reference strains. The aligned sequences were analyzed using MEGA 6.0 software (Tamura et al. 2013). The phylogenetic tree was constructed by neighbor joining using the TN93 model (Tamura \& Nei 1993). Statistical significance levels of interior nodes were determined by bootstrap analysis with 1000 replications.

\section{Susceptibility of Gram-positive and Gram-negative bacteria to BALOs}

The ability of BALOs to attack both Gram-positive and Gram-negative bacteria was investigated with Staphylococcus aureus, Escherichia coli, Vibrio vulnificus, V. cholerae, V. alginolyticus, AHPND Vp, and clinical and environmental $V$. parahaemolyticus isolates. A bacterial lawn was produced by shaking a loop full of each bacterium in LB broth for $3 \mathrm{~h}$ before mixing with melted DNAg and spreading on DNAg. To increase the titer of BALOs, each pure culture of BALO strain in DNB was mixed with AHPND Vp PSU 5429 and incubated with shaking at $30^{\circ} \mathrm{C}$ for $3 \mathrm{~d}$. The mixture was then filtered to remove the host bacterium, and $10 \mu \mathrm{l}$ of the filtrate were dropped on the plate containing the bacterial lawn. A clear zone was observed after incubation at $30^{\circ} \mathrm{C}$ for 3 to $7 \mathrm{~d}$. All experiments were performed in triplicate independently, and at least 1 positive out of the 3 experiments was defined as susceptible, whereas 3 negative experiments indicated nonsusceptibility.

\section{Optimal conditions of interaction between a BALO strain and AHPND Vp}

To assess factors that affect the ability of a BALO to inhibit AHPND Vp, we evaluated the multiplicity of infection of a selected BALO isolate and an AHPND Vp isolate including temperature, salinity, and pH. Each $1 \mathrm{ml}$ of a BALO designated as BV-A at concentrations of $10^{3}$ to $10^{6}$ plaque-forming units (PFU) $\mathrm{ml}^{-1}$ was incubated with $1 \mathrm{ml}$ AHPND Vp PSU 5429 suspension $\left(10^{7} \mathrm{CFU} \mathrm{m} \mathrm{m}^{-1}\right)$ in $100 \mathrm{ml} \mathrm{DNB}$ at a ratio between 1:10 and 1:10000. This co-culture was incubated with shaking at $30^{\circ} \mathrm{C}$ for $7 \mathrm{~d}$, and the numbers of AHPND $\mathrm{Vp}$ were enumerated daily by the plate count technique. To investigate the effect of temperature, the coculture was incubated with shaking at 25, 30, and $37^{\circ} \mathrm{C}$, and for salinity and $\mathrm{pH}$ evaluations, the co-culture was inoculated in DNB supplemented with 1 to $6 \% \mathrm{NaCl}$ at $\mathrm{pH}$ between 7 and 9 . For controls, general shrimp pond conditions were applied, AHPND Vp was inoculated in DNB supplemented with $2 \% \mathrm{NaCl}, \mathrm{pH}$ 7.6, and incubated with shaking at $30^{\circ} \mathrm{C}$. The experiment was performed in triplicate. The reduction of $V$. parahaemolyticus was calculated based on the percent difference between the initial numbers of the bacterium in the control before and after treatment.

\section{Potential of a BALO strain to suppress AHPND Vp in vitro}

Co-culture of a BALO strain and an AHPND Vp isolate was performed in the optimal conditions described above for $7 \mathrm{~d}$. A control for each organism was included. The numbers of BALO and AHPND Vp were enumerated daily using double-layer agar and spread plate techniques, respectively.

\section{Efficacy of a BALO strain to inhibit AHPND Vp in shrimp larvae}

To assess the ability of a BALO strain to reduce mortality in shrimp larvae infected with AHPND $\mathrm{Vp}$, whiteleg shrimp Litopenaeus vannamei postlarvae (PL24) were obtained from a shrimp farm in Songkhla Province, Thailand. Larvae were acclimatized in a tank containing 51 of $2 \%$ artificial sea water (ASW) with aeration at room temperature $\left(30^{\circ} \mathrm{C}\right)$ and fed with a commercial diet twice a day. The experiment was divided into 6 groups: ASW (PL24) control, AHPND Vp, BALO control, and AHPND Vp interactions with BALO at final concen- 
trations of $10^{2}, 10^{4}$ and $10^{6} \mathrm{PFU} \mathrm{ml}{ }^{-1}$. Briefly, PL24 were introduced into the tanks containing AHPND $\mathrm{Vp}$ at the final concentration of $10^{7} \mathrm{CFU} \mathrm{ml}^{-1}$, and various concentrations of BALO were added to the tanks after $15 \mathrm{~min}$. In each group, 20 shrimp larvae were investigated and 2 replicates were performed. The mortality of larvae was recorded daily for $7 \mathrm{~d}$.

\section{Biofilm assay}

To evaluate the ability of BALOs to remove biofilm formed by $V$. parahaemolyticus, the formation of biofilm by AHPND Vp and clinical and environmental $V$. parahaemolyticus isolates was assessed by quantitative determination (Nesper et al. 2001, Chanyi \& Koval 2014). Briefly, $200 \mu \mathrm{l}$ of an overnight culture of $V$. parahaemolyticus grown in LB broth supplemented with $2 \% \mathrm{NaCl}$ were inoculated into 96-well microtiter plates and incubated at room temperature $\left(30^{\circ} \mathrm{C}\right)$ for $24 \mathrm{~h}$. The wells were washed 3 times with water to remove planktonic cells, and $200 \mu \mathrm{l}$ of a BALO suspension $\left(10^{6} \mathrm{PFU} \mathrm{ml}^{-1}\right)$ in DNB were inoculated into the preformed $V$. parahaemolyticus biofilms and incubated at room temperature for $24 \mathrm{~h}$. The wells were then washed 3 times and fixed with glutaraldehyde. The cells were stained with $200 \mu \mathrm{l}$ of crystal violet $(0.4 \% \mathrm{w} / \mathrm{v})$ for $15 \mathrm{~min}$, washed with water and dried, then destained with ethanol-acetone (80:20). The biofilm production was analyzed by color development using a microplate reader at a wavelength of $570 \mathrm{~nm}$. Biofilm formation of either $V$. parahaemolyticus alone or a BALO strain alone including LB broth supplemented with $2 \% \mathrm{NaCl}$ was used as a control. In all experiments, the results obtained were an average of 12 wells.

\section{Statistical analysis}

Statistical analysis was carried out using SPSS 11.5 software to observe differences in each experiment. All values were subjected to 1-way analysis of variance (ANOVA). The data are presented as the mean and standard deviation (SD) for the indicated numbers of each experiment. Means were separated using Duncan's test at $\mathrm{p}<0.05$. The differences observed were considered statistically significant at $\mathrm{p}<0.05$.

\section{RESULTS}

\section{Isolation and identification of BALOs}

In total, 25 samples were collected including 13 water and 12 sediment samples from Yor Island and shrimp farms. Three BALO strains were isolated from the water and 6 from the sediment samples (Table 1). Confirmation by $16 \mathrm{~S}$ rRNA sequencing revealed that all of them were Bacteriovorax spp. with 89 to $100 \%$ homology to the reference strains in GenBank. A comparison of the phylogenetic tree analysis with 11 Bacteriovorax spp. reference strains in GenBank (see Fig. S1 in the Supplement at www.int-res.com/ articles/suppl/d124p223_supp.pdf) indicated that Bacteriovorax NBV 2-5 were 89 to $99 \%$ similar in sequence to the NE1, DA5, DD1, and NB2 reference strains. Bacterivorax MBV 5-6 showed 100\% homology to the RM2T4-S, RM3S1-S, RM2B2-S, RL1T4-S, RM3T4-S, and RM3S3-S reference strains, whereas Bacterivorax BV-A was $91 \%$ homologous to this group. Bacterivorax MBV 4 and NBV1 displayed around 94 to $100 \%$ similarity to BV-A and the rest of the Bacteriovorax obtained in this study (Table 1 and Fig. S1).
Table 1. Isolation of Bdellovibrio and like organisms (BALOs) from environmental samples and shrimp farms

\begin{tabular}{|llcclcr|}
\hline Source & $\begin{array}{l}\text { Sample } \\
\text { type }\end{array}$ & $\begin{array}{c}\text { No. of } \\
\text { positive } \\
\text { isolates }\end{array}$ & $\begin{array}{c}\text { Isolate } \\
\text { code }\end{array}$ & NCBI description & $\begin{array}{c}\text { Homo- } \\
\text { logy } \\
(\%)\end{array}$ \\
\hline Yor island & Water & 3 & MBV4 & Bacteriovorax sp. B3S2-S & 94 \\
& & & MBV5 & Bacteriovorax sp. RM3T4-S & 100 \\
& Sediment & 2 & NBV6 & Bacteriovorax sp. RM3T4-S & 100 \\
& & & NBV2 & Bacteriovorax sp. NE1 & 100 \\
Trang farm & Sediment & 1 & BV-A & Bacteriovorax sp. NE1 & 89 \\
Samutsongkram sp. DA5 & 91 \\
farm & Sediment & 2 & NBV3 & Bacteriovorax sp. NE1 & 99 \\
Songkhla farm & Sediment & 1 & NBV5 & Bacteriovorax sp. NE1 & 98 \\
\hline
\end{tabular}

\section{Susceptibility of Gram- positive and Gram-negative bacteria to BALOs}

The ability of 9 isolates of Bacteriovorax spp. to lyse Grampositive and Gram-negative bacteria, including Vibrio spp., was evaluated. Two isolates of Bacteriovorax spp. could attack Staphylococcus aureus, and 4 could predate E. coli, whereas 5 to 6 isolates possessed the ability to lyse Vibrio vulnificus, $V$. cholerae, and V. alginolyti- 
Table 2. Susceptibility of other bacteria (Staphylococcus aureus, Escherichia coli) and Vibrio spp. to Bacteriovorax spp. The experiment was performed independently 3 times; numbers shown are the numbers of positive experiments out of 3; dashes indicate that all 3 experiments were negative. Vv: Vibrio vulnificus; Vc: V. cholerae; Va: V. alginolyticus; Vp: V. parahaemolyticus; AHPND Vp: acute hepatopancreatic necrosis disease-causing $V$. parahaemolyticus

\begin{tabular}{|c|c|c|c|c|c|c|c|c|c|c|c|c|c|c|}
\hline \multirow{3}{*}{$\begin{array}{l}\text { Bacterio- } \\
\text { vorax } \\
\text { isolates }\end{array}$} & \multicolumn{2}{|c|}{ Other bacteria } & \multicolumn{3}{|c|}{ —Vibrio spp.— } & \multicolumn{5}{|c|}{$\begin{array}{l}- \text { Hosts } \\
\text { AHPND Vp }\end{array}$} & \multicolumn{4}{|c|}{$-V p$} \\
\hline & \multirow{2}{*}{\multicolumn{2}{|c|}{$\begin{array}{cc}S . & E . \\
\text { aureus } & \text { coli }\end{array}$}} & \multirow[t]{2}{*}{$\mathrm{Vv}$} & \multirow[t]{2}{*}{$\mathrm{Vc}$} & \multirow[t]{2}{*}{$\mathrm{Va}$} & \multirow{2}{*}{$\mathrm{EMS}_{1} \mathrm{~S}_{2}$} & \multirow[t]{2}{*}{ VP12 } & \multirow[t]{2}{*}{$7.2 \mathrm{~L} 3$} & \multirow{2}{*}{$\mathrm{PeP}_{16}$} & \multirow[t]{2}{*}{$6.1 \mathrm{~L} 3$} & \multicolumn{2}{|c|}{ Clinical } & \multicolumn{2}{|c|}{ Environmental } \\
\hline & & & & & & & & & & & PSU5666 & PSU5668 & PSU5147 & PSU5150 \\
\hline BV-A & +3 & +3 & +3 & +3 & +3 & +3 & +3 & +3 & +3 & +3 & +3 & - & - & +3 \\
\hline MBV4 & - & - & +2 & - & - & +3 & +3 & +3 & +3 & +3 & +3 & - & +3 & +3 \\
\hline MBV5 & +3 & - & - & +2 & +2 & +3 & +3 & +3 & +3 & +3 & - & - & - & - \\
\hline MBV6 & - & - & - & - & - & +3 & +3 & +3 & +3 & +3 & - & - & - & - \\
\hline NBV1 & - & - & +2 & - & +3 & +3 & +3 & +3 & +3 & +3 & - & - & - & - \\
\hline NBV2 & - & +2 & +3 & +3 & +3 & +3 & +3 & +3 & +3 & +3 & +3 & - & - & - \\
\hline NBV3 & - & +3 & +3 & +3 & +2 & +3 & +3 & +3 & +3 & +3 & +3 & +3 & +3 & +1 \\
\hline NBV4 & - & +3 & - & +2 & +3 & +3 & +3 & +3 & +3 & +3 & +3 & - & - & - \\
\hline NBV5 & - & - & - & +3 & - & +3 & +3 & +3 & +3 & +3 & - & +1 & - & - \\
\hline Total & 2 & 4 & 5 & 6 & 6 & 9 & 9 & 9 & 9 & 9 & 5 & 2 & 2 & 3 \\
\hline
\end{tabular}

cus (Table 2). All of them could lyse all 5 AHPND Vp tested isolates; however, only 2 to 5 isolates of Bacteriovorax spp. could attack clinical and environmental $V$. parahaemolyticus.

\section{Factors involved in interaction between a BALO strain and AHPND Vp}

To investigate the optimal ratio for the interaction of BALOs with AHPND Vp, Bacteriovorax BV-A was selected because it was isolated from a shrimp farm that was less severely affected by AHPND. In addition, it was able to attack many bacterial strains (Table 2). BV-A was incubated with AHPND Vp PSU 5429 at a ratio between 1:10 and 1:10000. Although the numbers of AHPND Vp continuously decreased in every interaction ratio after $1 \mathrm{~d}$ of incubation, the highest reduction in numbers of AHPND Vp (91.1\%) was detected at a ratio of 1:10 (Fig. 1). Thus, this ratio was used for interaction evaluation between these organisms throughout this study.

Reduction in numbers of AHPND $\mathrm{Vp}$ in coculture between BV-A and AHPND $\mathrm{Vp}$ in the whole period of time was greater at $30^{\circ} \mathrm{C}$ than at 25 or $37^{\circ} \mathrm{C}$ (Fig. S2A in the Supplement). In addition, 90.8 to $95.3 \%$ reduction in numbers of AHPND Vp was detected in the co-culture at $\mathrm{NaCl}$ concentrations between 1 and $3 \%$ (Fig. S2B). No significant

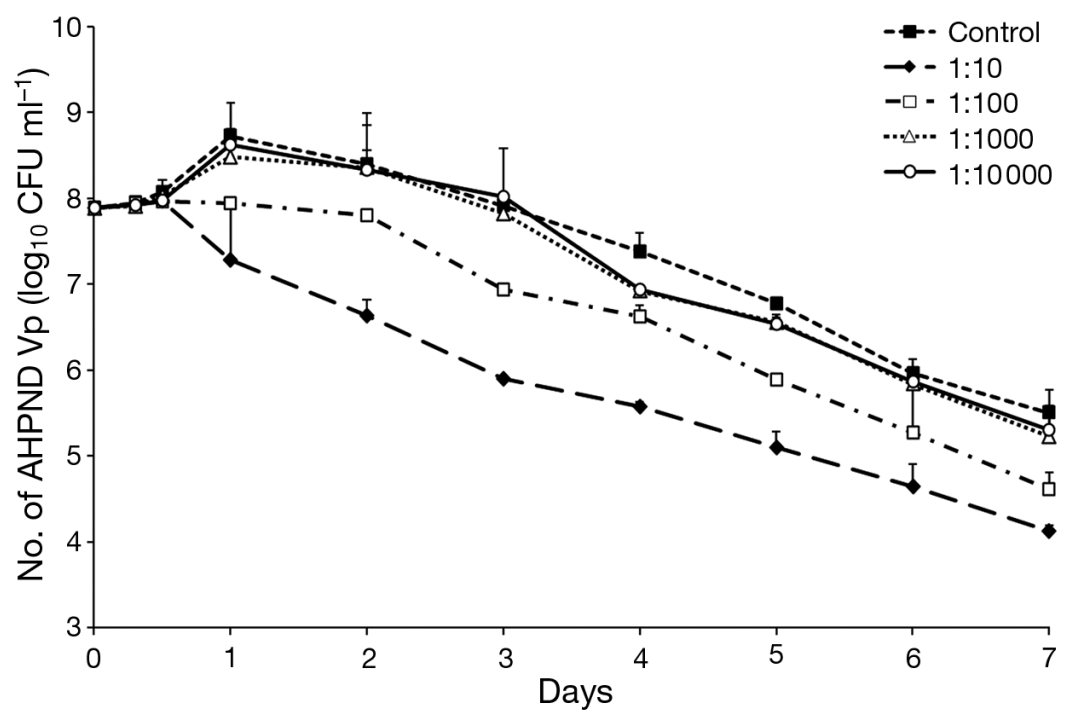

Fig. 1. Determination of the optimal ratio for interaction between Bacteriovorax BV-A and acute hepatopancreatic necrosis disease-causing Vibrio parahaemolyticus (AHPND Vp). BV-A was incubated with AHPND Vp at ratios between 1:10 and 1:10000 for $7 \mathrm{~d}$, and the numbers of AHPND Vp were enumerated daily. The control contained only AHPND Vp. Values are mean \pm SD of 2 experiments; each experiment was performed in triplicate. The highest reduction in numbers of AHPND Vp $(91.1 \%)$ was detected at a ratio of 1:10 difference in the reduction of AHPND Vp isolate was observed after co-cultivation with BV-A at $\mathrm{pH}$ between 7 and 8 (Fig. S2C). In Thailand, the level of salinity in shrimp farms is between 1 and $3 \%$ (Flaherty et al. 2000), and the ambient temperature is $30^{\circ} \mathrm{C}$. Therefore, $2 \% \mathrm{NaCl}$ and $30^{\circ} \mathrm{C}$ were applied for subsequent co-culture of Bacteriovorax and AHPND Vp in DNB at $\mathrm{pH}$ 7.6. This $\mathrm{pH}$ was selected because the typical $\mathrm{pH}$ of seawater lies between 7.5 and 8.4, and the appropriate $\mathrm{pH}$ of 


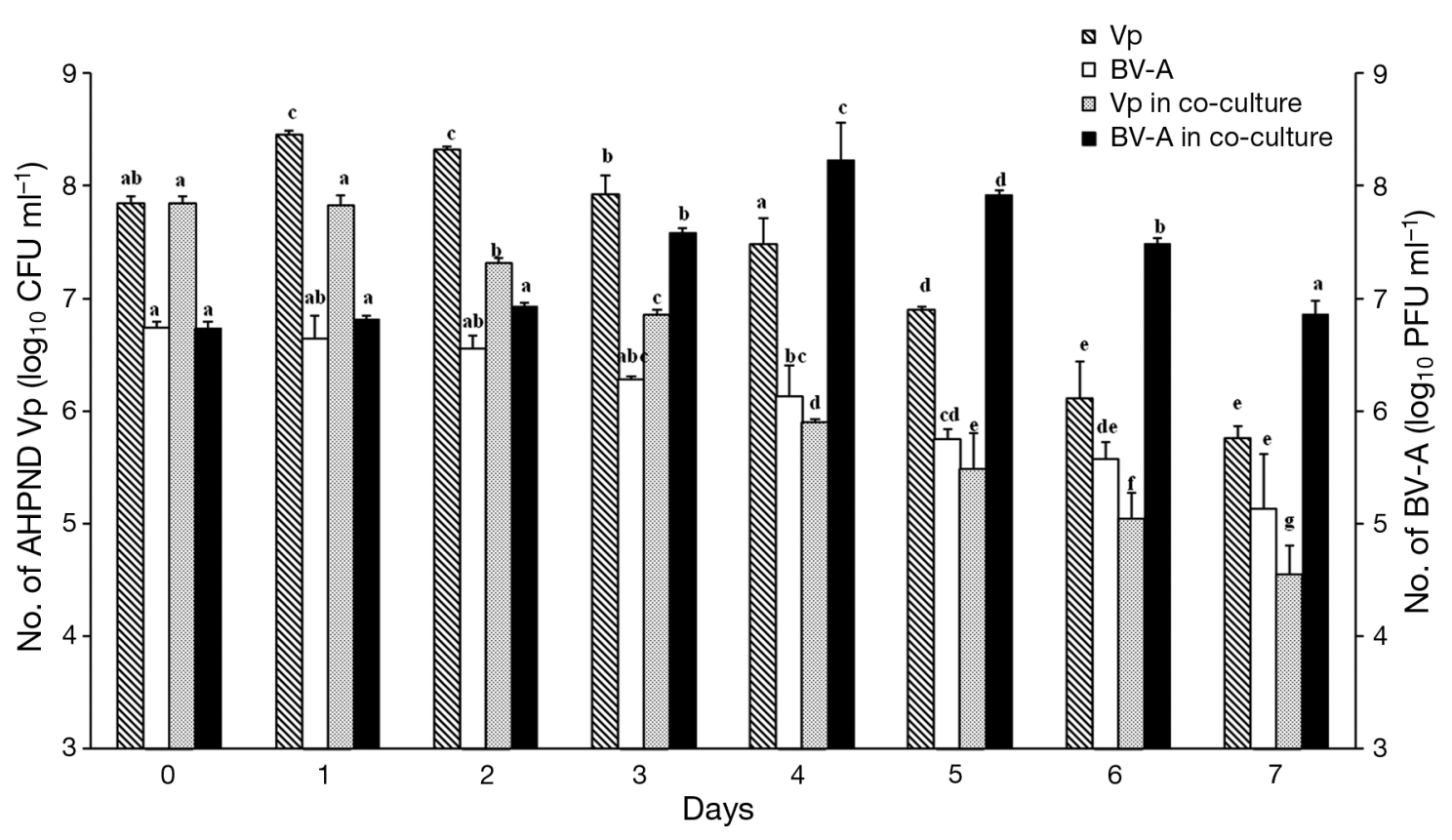

Fig. 2. Potential of Bacteriovorax BV-A to inhibit acute hepatopancreatic necrosis disease-causing Vibrio parahaemolyticus (AHPND Vp) in vitro. BV-A was co-cultured with AHPND Vp for $7 \mathrm{~d}$, and each organism was enumerated daily and compared to the BV-A and AHPND Vp controls. Values are mean \pm SD of 2 experiments. Different letters above bars show values that are significantly different $(p<0.05)$. Each value is compared within each category

water in shrimp ponds should be maintained between 7.5 and 8.5 (Anh et al. 2010).

\section{In vitro interaction between a BALO strain and AHPND Vp}

One milliliter each of BV-A $\left(10^{6} \mathrm{PFU} \mathrm{ml}{ }^{-1}\right)$ and AHPND Vp PSU $5429\left(10^{7} \mathrm{CFU} \mathrm{ml}^{-1}\right)$ were mixed in $100 \mathrm{ml}$ of DNB containing $2 \% \mathrm{NaCl}_{1} \mathrm{pH} 7.6$, and incubated at $30^{\circ} \mathrm{C}$. After $2 \mathrm{~d}$ of incubation, the numbers of AHPND Vp were significantly lower than in the AHPND Vp control and continuously decreased over the following days (Fig. 2). However, the numbers of BV-A significantly increased after $3 \mathrm{~d}$ of incubation and continued to do so until Day 5 of incubation, before decreasing until Day 7 . In the AHPND Vp control group, the bacterial numbers significantly increased during Day 1 and 3 of incubation and subsequently decreased from Days 5 to 7, whereas a slight decrease in numbers of the BVA control was detected on Day 1 and carried on to Day 7.

\section{In vivo reduction of shrimp larval mortality by $\mathrm{BV}-\mathrm{A}$}

Shrimp post-larvae (PL24) were inoculated with AHPND Vp PSU 5429 at a final concentration of $10^{7}$
$\mathrm{CFU} \mathrm{ml}{ }^{-1}$, and various final concentrations of BV-A between $10^{2}$ and $10^{6} \mathrm{PFU} \mathrm{ml}{ }^{-1}$ were added into the shrimp tanks. The mortality of the post-larvae was determined daily for $7 \mathrm{~d}$. On Day 1, approximately $7.5,2.5,2.5$, and $0 \%$ of PL24 were dead in the AHPND Vp control and in the infected post-larval groups treated with $10^{2}, 10^{4}$, and $10^{6} \mathrm{PFU} \mathrm{ml}{ }^{-1} \mathrm{BV}-\mathrm{A}$, respectively; dead post-larvae in those groups increased to $50.0,30.0,20.0$, and $17.5 \%$ on Day 3 (Fig. 3). At the end of treatment, more than $90 \%$ of post-larvae were dead in the AHPND Vp control, whereas in the infected groups containing BV-A at final concentrations of $10^{2}, 10^{4}$, and $10^{6} \mathrm{PFU} \mathrm{ml}^{-1}$, mortality was $72.5,62.5$, and $47.5 \%$, respectively. No post-larvae died in the post-larvae and BV-A control groups.

\section{Reducing V. parahaemolyticus biofilm formation by BV-A}

AHPND Vp and clinical and environmental $V$. parahaemolyticus isolate biofilms were pre-formed in 96-well microtiter plates for $24 \mathrm{~h}$, the planktonic cells were removed, and the remaining biofilms were evaluated after adding BV-A and further incubated for $24 \mathrm{~h}$. Biofilm formation of the 3 categories of $V$. parahaemolyticus was significantly reduced by BV-A (Fig. 4). 


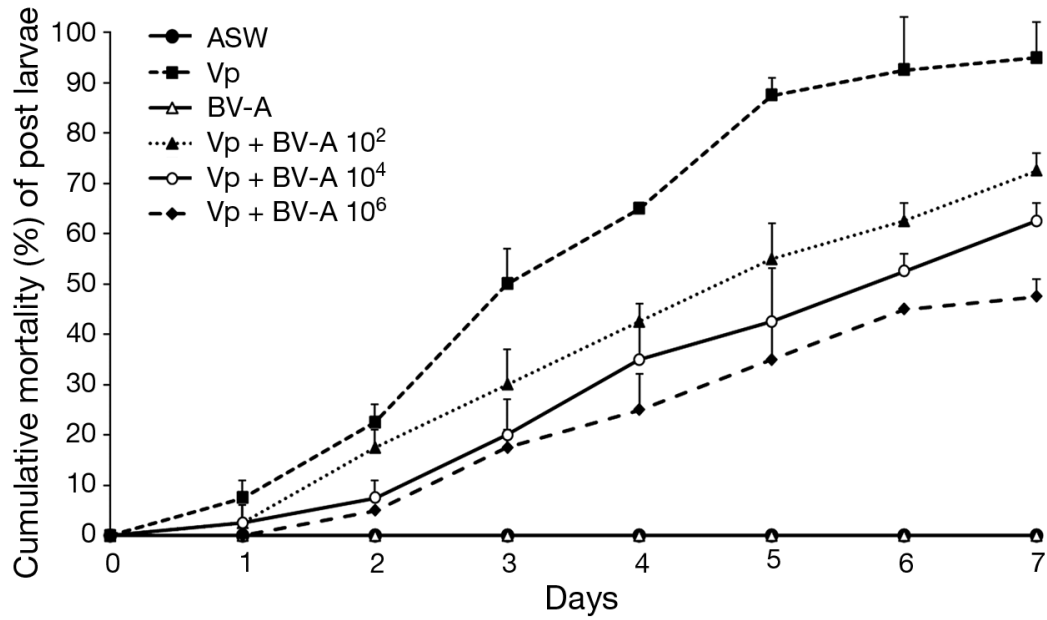

Fig. 3. Efficacy of Bacteriovorax BV-A to decrease shrimp post-larval mortality after treatment with acute hepatopancreatic necrosis disease-causing $V i b$ rio parahaemolyticus (AHPND Vp). Litopenaeus vannamei post-larvae (PL24) were exposed to AHPND Vp and subsequently treated with Bacteriovorax BV-A at concentrations of $10^{2}, 10^{4}$, and $10^{6}$ plaque-forming units (PFU) ml ${ }^{-1}$. Dead post-larvae were counted daily. PL24 treated with artificial seawater (ASW), AHPND Vp $\left(10^{7} \mathrm{CFU} \mathrm{ml}^{-1}\right)$, or BV-A $\left(10^{6} \mathrm{PFU} \mathrm{ml} \mathrm{m}^{-1}\right)$ alone were used as controls

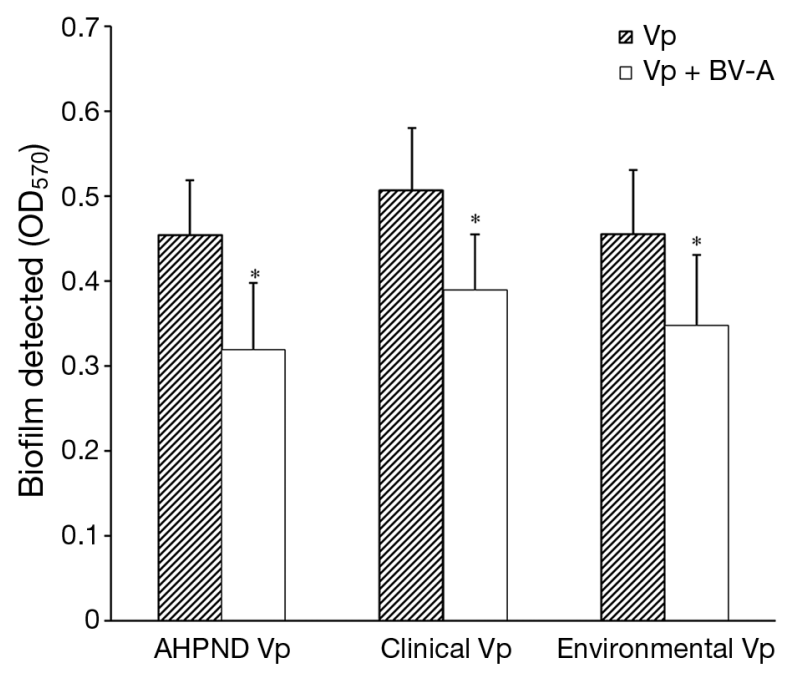

Fig. 4. Capability of Bacteriovorax BV-A to decrease biofilm formation of acute hepatopancreatic necrosis diseasecausing Vibrio parahaemolyticus (AHPND Vp) and clinical and environmental isolates of $V$. parahaemolyticus. $V$. parahaemolyticus biofilms were pre-formed in 96-well microtiter plates for $24 \mathrm{~h}$, and BV-A suspension was added after removal of planktonic cells. Biofilm was quantitated using crystal violet staining. ${ }^{*}$ indicates significant differences $(p<0.05)$

\section{DISCUSSION}

AHPND has caused an economic crisis in shrimp aquaculture. BALOs are ubiquitously distributed in the environment and target many prey bacteria. This makes them an attractive candidate for control of
Vibrio parahaemolyticus, the causative agent of AHPND. In this work, various samples were obtained from Yor Island and infected shrimp farms. This island was selected because it is close to many shrimp farms located on the peninsular coast, and BALOs prefer to attack bacteria from the same environment (Pineiro et al. 2004). The organisms were more predominant in sediment than in water; 6 out of 12 sediments were positive $(50 \%)$, but they were only detected in 3 out of 13 water samples (23\%; Table 1). 16S rRNA sequencing was performed for identification of all BALOs obtained in this study without any further identification; therefore, the isolates were specified as the genus of their closest BLAST homology. Although all of the isolates collected from Yor Island were identified as Bacteriovorax spp., phylogenetic analysis differentiated 2 of them (MBV4 and NBV1) with $100 \%$ confidence because they formed an independent branch (Fig. S1). Previously, there had been no evidence that Grampositive bacteria were susceptible to BALOs; recently, however, Bdellovibrio bacteriovorus HD 100 has been demonstrated to decrease numbers of Staphylococcus aureus in broth culture (Iebba et al. 2014). In the present study, only 2 out of 9 Bacteriovorax spp. (BV-A and MBV-5) were able to attack $S$. aureus (Table 2). However, all of them could lyse all AHPND Vp tested isolates, whereas their capabilities to attack clinical and environmental V. parahaemolyticus were lower. This may be because most of the Bacteriovorax spp. were isolated from AHPNDaffected shrimp ponds, and AHPND Vp PSU 5429 was used as a host for propagation. In this work, although MBV-5 and MBV-6 showed 100\% homology to Bacteriovorax RM3S3-S including the other 6 Bacteriovorax reference strains (Fig. S1), their bacteriolytic activities toward prey bacteria were slightly different (Table 2). The information of $16 \mathrm{~S}$ sequencing might not be enough to differentiate some BALO strains. The gene encoding the $\beta$-subunit of RNA polymerase $(r p o B)$ is more discriminating than the 16S rRNA gene for differentiation of saltwater members of the genus Bacteriovorax (Pineiro et al. 2008). Additionally, the mechanism of BALOs to select their prey is not clearly understood, and variability in prey range between 2 closely related BALO strains has been documented (Chanyi et al. 2013). 
The optimal ratio for interaction between Bacteriovorax BV-A and AHPND Vp was evaluated. In this work, AHPND Vp PSU 5429 at a concentration of $10^{7}$ $\mathrm{CFU} \mathrm{ml}^{-1}$ was selected for the assay because investigation of AHPND in a shrimp farm in Mexico revealed that different virulence of $V$. parahaemolyticus depended on bacterial density, and the minimum infective density was $10^{4} \mathrm{CFU} \mathrm{ml}^{-1}$ (Soto-Rodriguez et al. 2015). In addition, no shrimp mortality was observed at densities below this value, and less virulent strains did not induce $100 \%$ mortality. In our study, the reduction of AHPND Vp isolates was highest at a ratio of 1:10 between BV-A and AHPND Vp. Thus, this ratio was used for the consecutive assays.

To evaluate the capability of Bacteriovorax BV-A to decrease numbers of AHPND Vp in vitro, co-culture of those organisms was conducted. Each of AHPND $\mathrm{Vp}$ and BV-A was included for comparison. We found that at the end of incubation (Day 7), the numbers of both control organisms had decreased (Fig. 2). This might be due to the depletion of nutrients in DNB as the growth of AHPND Vp approached the decline phase, whereas reduction of BV-A was due to the lack of prey. In co-culture, the numbers of AHPND $\mathrm{Vp}$ decreased significantly more than that of the control group, indicating the potential of BV-A to eliminate this bacterium. This was clearly apparent on Day 2 of incubation, and the numbers of BV-A started increasing in the subsequent days. On Day 5, the numbers of BV-A in co-culture started decreasing, and this continued until the end of the incubation period, suggesting that this decline might be due to the decrease in numbers of prey.

To evaluate the effectiveness of BALOs in the prevention of AHPND $\mathrm{Vp}$ infection in shrimp, a different concentration of BV-A was applied to AHPND Vp-infected PL24. Post-larval mortality was decreased after treatment with the high concentration of BV-A (Fig. 3). This indicates the protective efficacy of BALO for post-larval shrimp. However, in this study, the mortality of post-larvae was reduced by approximately $50 \%$ with a $1: 10$ ratio of BV-A to AHPND Vp. Therefore, to improve the effectiveness of the treatment, a higher concentration of BALO is suggested.

$V$. parahaemolyticus can form biofilms on shrimp surfaces (Han et al. 2016). Investigation of 35 AHPND Vp isolates derived from shrimp farms in Mexico revealed that all of them were able to form moderate to strong biofilms (López-Leónl et al. 2016). In shrimp farming, the molting process of shrimp causes an accumulation of bacterial biofilms at the bottom of the pond. Iebba et al. (2014) reported that
BALOs could target their prey both in water and in biofilm. In the current work, we demonstrated the potential of BV-A to significantly diminish biofilm formed by AHPND Vp and by clinical and environmental V. parahaemolyticus isolates (Fig. 4). Therefore, this evidence supports the advantage of using Bacteriovorax as a biocontrol in shrimp aquaculture.

BALOs have a wide prey range, but the way they select their prey is not well understood (Rogosky et al. 2006, Chen et al. 2011). Bdellovibrio directs itself towards its prey by flagellar motility and chemotactic responses (Straley \& Conti 1977, Lambert et al. 2003). Pilus fibers may also be involved in the early stage of predation. Three pilA mutants of Bdellovibrio bacteriovorus were unable to attack their prey compared with the wild type (Evans et al. 2007). In addition, Bd0112 (homologue to pilQ) and Bd3852 (homologue to 1 of 2 pilT) are implicated in B. bacteriovorus predation (Medina et al. 2008). BALOs generally possess a periplasmic life cycle; however, recently, an epibiotic life cycle has been demonstrated in the Gram-negative bacteria Acinetobacter, Aeromonas, Caulobacter, and Delftia (Chanyi et al. 2013). In the epibiotic life cycle, predators attach to the prey surface and perform binary fission on the outer surface of the prey cell while prey cytoplasmic contents decrease. Iebba et al. (2014) demonstrated that $B$. bacteriovorus HD 100 attacked $S$. aureus in the epibiotic style. In addition, Monnappa et al. (2014) reported extracellular protease released from $B$. bacteriovorus HD 100 to degrade $S$. aureus biofilm and reduce its virulence. We do not know which life cycle(s) Bacteriovorax BV-A obtained in this work uses for attacking AHPND Vp. It would be of interest to determine the attack mechanism of this predator in the future.

In conclusion, this work demonstrates the potential of BALOs to control AHPND Vp in shrimp farms. One genus of BALOs (Bacteriovorax) was predominantly isolated from water and sediment samples. The optimal ratio of Bacteriovorax BV-A to interact with AHPND Vp was 1:10. In vitro, BV-A decreased the numbers of AHPND Vp within $2 \mathrm{~d}$ of the co-culture, and in vivo, it reduced mortality of post-larvae infected with AHPND Vp by around 50\%. This indicates the preventive efficiency of BALOs in the control of AHPND Vp in shrimp aquaculture.

Acknowledgements. This work was supported in part by a subcontract from grant A27134 from CPF (Thailand) awarded to Harvard University and in part by the Royal Golden Jubilee PhD Program, Thailand Research Fund (Grant No. PHD/0213/2556). 


\section{LITERATURE CITED}

Anh PT, Kroeze C, Bush SR, Mol APJ (2010) Water pollution by intensive brackish shrimp farming in south-east Vietnam: causes and options for control. Agric Water Manag 97:872-882

Cao H, He S, Wang H, Hou S, Lu L, Yang X (2012) Bdellovibrios, potential biocontrol bacteria against pathogenic Aeromonas hydrophila. Vet Microbiol 154:413-418

Chanyi RM, Koval SF (2014) Role of Type IV pili in predation by Bdellovibrio bacteriovorus. PLOS ONE 9:e113404

Chanyi RM, Ward C, Pechey A, Koval SF (2013) To invade or not to invade: two approaches to a prokaryotic predatory life cycle. Can J Microbiol 59:273-279

Chen H, Athar R, Zheng G, Williams HN (2011) Prey bacteria shape the community structure of their predators. ISME J 5:1314-1322

* Chu WH, Zhu W (2010) Isolation of Bdellovibrio as biological therapeutic agents used for the treatment of Aeromonas hydrophila infection in fish. Zoonoses Public Health 57: 258-264

* Dashiff A, Junka RA, Libera M, Kadouri DE (2011) Predation of human pathogens by the predatory bacteria Micavibrio aeruginosavorus and Bdellovibrio bacteriovorus. J Appl Microbiol 110:431-444

Davidov Y, Friedjung A, Jurkevitch E (2006) Structure analysis of a soil community of predatory bacteria using culture-dependent and culture independent methods reveals a hitherto undetected diversity of Bdellovibrioand-like organisms. Environ Microbiol 8:1667-1673

Evans KJ, Lambert C, Sockett RE (2007) Predation by Bdellovibrio bacteriovorus HD100 requires type IV pili. J Bacteriol 189:4850-4859

Flaherty M, Szuster B, Miller P (2000) Low salinity inland shrimp farming in Thailand. Ambio 29:174-179

Fratamico PM, Cooke PH (1996) Isolation of Bdellovibrios that prey on Escherichia coli O157:H7 and Salmonella species and application for removal of prey from stainless steel surfaces. J Food Saf 16:161-173

*Han N, Mizan MFR, Jahid IK, Ha SD (2016) Biofilm formation by Vibrio parahaemolyticus on food and food contact surfaces increases with rise in temperature. Food Control 70:161-166

Hong XP, Xu D, Zhuo Y, Liu HQ, Lu LQ (2016) Identification and pathogenicity of Vibrio parahaemolyticus isolates and immune responses of Penaeus (Litopenaeus) vannamei (Boone). J Fish Dis 39:1085-1097

Iebba V, Totino V, Santangelo F, Gagliardi A and others (2014) Bdellovibrio bacteriovorus directly attacks Pseudomonas aeruginosa and Staphylococcus aureus cystic fibrosis isolates. Front Microbiol 5:280

Joshi J, Srisala J, Truong VH, Chen IT and others (2014) Variation in Vibrio parahaemolyticus isolates from a single Thai shrimp farm experiencing an outbreak of acute hepatopancreatic necrosis disease (AHPND). Aquaculture 428-429:297-302

*Jurkevitch E, Minz D, Ramati B, Barel G (2000) Prey range characterization, ribotyping, and diversity of soil and rhizosphere Bdellovibrio spp. isolated on phytopathogenic bacteria. Appl Environ Microbiol 66:2365-2371

Kongrueng J, Yingkajorn M, Bunpa S, Sermwittayawong N, Singkhamanan N, Vuddhakul V (2015) Characterization of Vibrio parahaemolyticus causing acute hepatopancreatic necrosis disease in southern Thailand. J Fish Dis 38:957-966
Lai HC, Ng TH, Ando M, Lee CT and others (2015) Pathogenesis of acute hepatopancreatic necrosis disease (AHPND) in shrimp. Fish Shellfish Immunol 47:1006-1014

* Lambert C, Smith MCM, Sockett RE (2003) A novel assay to monitor predator-prey interactions for Bdellovibrio bacteriovorus 109J reveals a role for methyl-accepting chemotaxis proteins in predation. Environ Microbiol 5: $127-132$

* Li H, Liu C, Chen L, Zhang X, Cai J (2011) Biological characterization of two marine Bdellovibrio-and-like organisms isolated from Daya bay of Shenzhen, China and their application in the elimination of Vibrio parahaemolyticus in oyster. Int J Food Microbiol 151:36-43

* Li H, Chen C, Sun Q, Liu R, Cai J (2014) Bdellovibrio and like organisms enhanced growth and survival of Penaeus monodon and altered bacterial community structures in its rearing water. Appl Environ Microbiol 80:6346-6354

López-Leónl P, Luna-González A, Escamilla-Montes R, Flores-Miranda MC, Fierro-Coronadol JA, Álvarez-Ruiz P, Diarte-Plata G (2016) Isolation and characterization of infectious Vibrio parahaemolyticus, the causative agent of AHPND, from the whiteleg shrimp (Litopenaeus vannamei). Lat Am J Aquat Res 44:470-479

*Medina AA, Shanks RM, Kadouri DE (2008) Development of a novel system for isolating genes involved in predatorprey interactions using host independent derivatives of Bdellovibrio bacteriovorus 109J. BMC Microbiol 8:33

* Monnappa AK, Dwidar M, Seo JK, Hur JH, Mitchell RJ (2014) Bdellovibrio bacteriovorus inhibits Staphylococcus aureus biofilm formation and invasion into human epithelial cells. Sci Rep 4:3811

*Nesper J, Lauriano CM, Klose KE, Kapfhammer D, Kraiss A, Reidl J (2001) Characterization of Vibrio cholerae O1 El tor galU and galE mutants: influence on lipopolysaccharide structure, colonization, and biofilm formation. Infect Immun 69:435-445

*Nunan L, Lightner D, Pantoja C, Gomez-Jimenez S (2014) Detection of acute hepatopancreatic necrosis disease (AHPND) in Mexico. Dis Aquat Org 111:81-86

* Pineiro SA, Sahaniuk GE, Romberg E, Williams HN (2004) Predation pattern and phylogenetic analysis of Bdellovibrionacea from the Great Salt Lake, Utah. Curr Microbiol 48:113-117

Pineiro SA, Williams HN, Stine OC (2008) Phylogenetic relationships amongst the saltwater members of the genus Bacteriovorax using $r p o B$ sequences and reclassification of Bacteriovorax stolpii as Bacteriolyticum stolpii gen. nov., comb. nov. Int J Syst Evol Microbiol 58:1203-1209

Rogosky AM, Moak PL, Emmert EA (2006) Differential predation by Bdellovibrio bacteriovorus 109J. Curr Microbiol 52:81-85

Sockett RE, Lambert C (2004) Bdellovibrio as therapeutic agents: a predatory renaissance? Nat Rev Microbiol 2: 669-675

* Soto-Rodriguez SA, Gomez-Gil B, Lozano-Olvera R, Betancourt-Lozano M, Morales-Covarrubias MS (2015) Field and experimental evidence of Vibrio parahaemolyticus as the causative agent of acute hepatopancreatic necrosis disease of cultured shrimp (Litopenaeus vannamei) in Northwestern Mexico. Appl Environ Microbiol 81: 1689-1699

Starr MP (1975) Bdellovibrio as symbiont; the associations of Bdellovibrios with other bacteria interpreted in terms of a generalized scheme for classifying organismic associations. Symp Soc Exp Biol 29:93-124 
Straley SC, Conti SF (1977) Chemotaxis by Bdellovibrio bacteriovorus toward prey. J Bacteriol 132:628-640

Tamura K, Nei M (1993) Estimation of the number of nucleotide substitutions in the control region of mitochondrial DNA in humans and chimpanzees. Mol Biol Evol 10: 512-526

Tamura K, Stecher G, Peterson D, Filipski A, Kumar S (2013) MEGA6: Molecular evolutionary genetics analysis version 6.0. Mol Biol Evol 30:2725-2729

Tran L, Nunan L, Redman RM, Mohney LL, Pantoja CR, Fitzsimmons K, Lightner DV (2013) Determination of the

Editorial responsibility: Jeffrey Shields,

Gloucester Point, Virginia, USA infectious nature of the agent of acute hepatopancreatic necrosis syndrome affecting penaeid shrimp. Dis Aquat Org 105:45-55

Williams HN, Pineiro SA (2006) Ecology of the predatory Bdellovibrio and like organisms. Microbiol Monogr 4: 213-248

* Yang YT, Chen IT, Lee CT, Chen CY and others (2014) Draft genome sequences of four strains of Vibrio parahaemolyticus, three of which cause early mortality syndrome/ acute hepatopancreatic necrosis disease in shrimp in China and Thailand. Genome Announc 2:e00816-14

Submitted: October 4, 2016; Accepted: March 6, 2017

Proofs received from author(s): April 14, 2017 